\title{
Al-La-Zr (Aluminum-Lanthanum-Zirconium)
}

\section{Raghavan}

Recently, [2010Pen] determined an isothermal section for this ternary system at $500{ }^{\circ} \mathrm{C}$, which depicts no ternary phases.

\section{Binary Systems}

The Al-La phase diagram [2010Pen, Massalski2] depicts the following intermediate phases: $\mathrm{AlLa}_{3}\left(D 0_{19}, \mathrm{Ni}_{3} \mathrm{Sn}\right.$-type hexagonal), $\mathrm{AlLa}_{2}$ (tetragonal), $\mathrm{Al}_{4} \mathrm{La}_{5}$ (space group $P \overline{6} 2 \mathrm{~m}$ ), AlLa (CeAl-type orthorhombic), $\mathrm{Al}_{2} \mathrm{La}\left(C 15, \mathrm{MgCu}_{2}\right.$-type

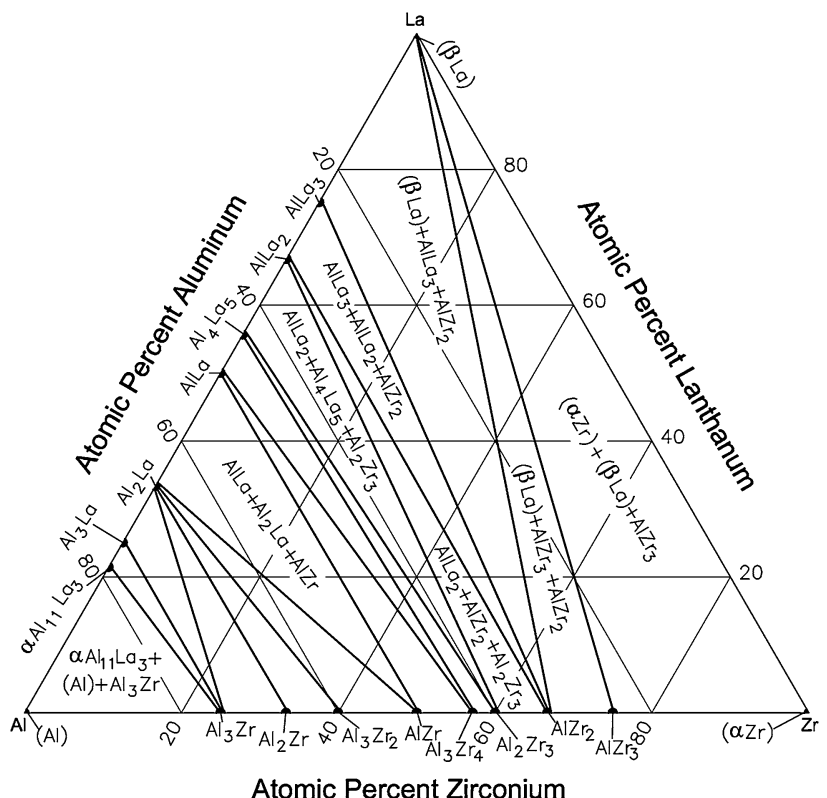

Fig. 1 Al-La-Zr isothermal section at $500{ }^{\circ} \mathrm{C}$ [2010Pen]. Narrow two-phase regions are omitted cubic), $\mathrm{Al}_{7} \mathrm{La}_{3}$ (stable between 1240 and $1090{ }^{\circ} \mathrm{C}$; C32, $\mathrm{AlB}_{2}$-type hexagonal), $\mathrm{Al}_{3} \mathrm{La}\left(\mathrm{Ni}_{3} \mathrm{Sn}\right.$-type hexagonal), $\beta \mathrm{Al}_{11} \mathrm{La}_{3}\left(D 1_{3}, \mathrm{Al}_{4} \mathrm{Ba}\right.$-type tetragonal), and $\alpha \mathrm{Al}_{11} \mathrm{La}_{3}$ $\left(\alpha \mathrm{Al}_{11} \mathrm{La}_{3}\right.$-type orthorhombic). The $\mathrm{Al}-\mathrm{Zr}$ phase diagram [Massalski2] depicts the following intermediate phases: $\mathrm{Al}_{3} \mathrm{Zr}$ ( $D 0_{23}$-type tetragonal), $\mathrm{Al}_{2} \mathrm{Zr}\left(C 14, \mathrm{MgZn}_{2}\right.$-type hexagonal), $\mathrm{Al}_{3} \mathrm{Zr}_{2}\left(\mathrm{Al}_{3} \mathrm{Zr}_{2}\right.$-type orthorhombic), $\mathrm{AlZr}\left(B_{f}\right.$, CrB-type orthorhombic), $\mathrm{Al}_{4} \mathrm{Zr}_{5}\left(\mathrm{Ga}_{4} \mathrm{Ti}_{5}\right.$-type hexagonal), $\mathrm{Al}_{3} \mathrm{Zr}_{4}\left(\mathrm{Al}_{3} \mathrm{Ir}_{4}\right.$-type hexagonal), $\mathrm{Al}_{2} \mathrm{Zr}_{3}\left(\mathrm{Al}_{2} \mathrm{Zr}_{3}\right.$-type tetragonal), $\mathrm{Al}_{3} \mathrm{Zr}_{5} \quad\left(D 8_{m}, \mathrm{~W}_{5} \mathrm{Si}_{3}\right.$-type tetragonal), $\mathrm{AlZr}_{2}$ $\left(B 8_{2}, \mathrm{Ni}_{2} \mathrm{In}\right.$-type hexagonal), and $\mathrm{AlZr}_{3}\left(L 1_{2}, \mathrm{AuCu}_{3}\right.$-type cubic). There are no intermediate phases in the $\mathrm{La}-\mathrm{Zr}$ system and the mutual solubility between $\mathrm{La}$ and $\mathrm{Zr}$ is negligible.

\section{Ternary Isothermal Section}

With starting metals of $99.9 \% \mathrm{Al}, 99.99 \% \mathrm{La}$ and 99.99\% Zr, [2010Pen] arc-melted 61 alloys under Ar atm. After homogenization, the alloys were given a final anneal at $500{ }^{\circ} \mathrm{C}$ for $>240 \mathrm{~h}$ and quenched in liquid nitrogen. The phase equilibria were studied with $\mathrm{x}$-ray powder diffraction and energy dispersive $\mathrm{x}$-ray analysis attached to the scanning electron microscope. The isothermal section at $500^{\circ} \mathrm{C}$ constructed by [2010Pen] is shown in Fig. 1. The binary compounds $\mathrm{Al}_{7} \mathrm{La}_{3}, \mathrm{Al}_{4} \mathrm{Zr}_{5}$ and $\mathrm{Al}_{3} \mathrm{Zr}_{5}$ are not stable at this temperature. No ternary phase is present. The solubility of the third component in the binary compounds is negligible [2010Pen].

\section{References}

2010Pen: D. Peng, Y. Zhan, J. She, M. Pang, and Y. Du, Phase Equilibria in the Ternary Al-Zr-La System, J. Alloys Compd., 2010, 507, p 62-66 